\title{
Teachers as memory makers: Testimony in the making of a new history in South Africa
}

\section{Citation}

Dryden-Peterson, Sarah, and Rob Siebörger. 2006. “Teachers as Memory Makers: Testimony in the Making of a New History in South Africa." International Journal of Educational Development 26 (4) (July): 394-403.

\section{Published Version}

doi:10.1016/j.ijedudev.2005.09.008

\section{Permanent link}

http://nrs.harvard.edu/urn-3:HUL.InstRepos:25378643

\section{Terms of Use}

This article was downloaded from Harvard University's DASH repository, and is made available under the terms and conditions applicable to Other Posted Material, as set forth at http:// nrs.harvard.edu/urn-3:HUL.InstRepos:dash.current.terms-of-use\#LAA

\section{Share Your Story}

The Harvard community has made this article openly available.

Please share how this access benefits you. Submit a story.

Accessibility 


\title{
TEACHERS AS MEMORY MAKERS: TESTIMONY IN THE MAKING OF A NEW HISTORY IN SOUTH AFRICA
}

\author{
Sarah Dryden-Peterson ${ }^{1,}{ }^{*}$ and Rob Siebörger ${ }^{2}$
}

\footnotetext{
${ }^{1}$ Graduate School of Education, Harvard University, Cambridge, MA 02138 USA

${ }^{*}$ Corresponding author. Tel: + 1-617-493-7841. E-mail address: sarah_dryden@post.harvard.edu

${ }^{2}$ School of Education, University of Cape Town, Rondebosch 7701, South Africa.
} 


\begin{abstract}
This article examines the use of testimony in the making of a new history in South Africa, situating this phenomenon in the context of public construction of memory and identifying history teachers as critical to the process. Through an ethnographic study of sixteen schools that illuminates the use of teacher testimony in Cape Town history classrooms, the authors explore the nuanced use of testimony as a pedagogic tool and probe the role of history teachers as memory makers. Finally, this article assesses implications of teachers creating space for dialogical memory making in post-apartheid South Africa and outlines lessons of this experience for other countries in democratic transition.
\end{abstract}

\title{
Key words
}

Comparative education

Curriculum

History teaching

South Africa

\section{Biographical Notes}

Sarah Dryden-Peterson is an Ed.D. Candidate at the Harvard Graduate School of Education, with interests in history teaching, local integration of refugees in countries of first asylum, and the role of schools in the reception of immigrants and refugees.

Rob Siebörger is an Associate Professor in the School of Education at the University of Cape Town, with special interests in history education, curriculum, assessment and initial teacher education. 


\section{Introduction}

Since the early 1990s, a new vision of South African society has been expressed in various forms. ${ }^{i}$ Most powerful among them is the Constitution, the legal and philosophic foundation of the new country, based on democracy and equality, nonracialism and opportunity. For this vision to take hold, however, citizens and institutions must engage with its principles through dialogue, negotiation, and contestation about its meaning and application. Central mechanisms in this endeavor are the system of education, which has the physical potential to reach every citizen, and the public construction (and deconstruction) of memory, which can reach deeply into citizens’ minds and imaginations.

At the intersection of these two institutions are South Africa's teachers. They have the potential to be role models for and brokers to a new future, under a new dispensation. They are also memory makers for a new South Africa. Their testimony provides for students a counter-text, tangible alternatives to 'official' history and onesided presentations of memory. In resisting the need for uniform 'truth', teachers use lived experience — their testimony — to engage students in interpretive acts and to create spaces for the practice of dialogue and dissent.

\section{Public Construction of Memory in South Africa}

Teachers' participation in the construction of memory is part of a larger phenomenon. During apartheid, some history teachers drew on their personal narratives to question and challenge apartheid ideology and to reaffirm human dignity and self-worth (Molteno, 1980; Reeves, 1994; Wieder, 2003). At the same time, oral history gained 
momentum among social historians, particularly under the auspices of the History Workshop. The creation of 'people’s history'—also called 'history from below' — was intensely political (Bozzoli \& Delius, 1990: 28). Specifically, this history aimed to overcome the silences of written sources and the hegemonic apartheid-era South African history (Cohen, Miescher \& White, 2001: 1-27) and to serve as a mechanism “whereby academics could attempt to reconcile their intellectual and political commitments”(Bozzoli \& Delius, 1990: 28). Minkley and Rassool, emphasise that “[t]his approach saw oral testimony as the voice of authenticity”(1998: 89).

Emphasis on oral history has been stronger in South Africa since the fall of apartheid as South Africans have been encouraged to understand the past, especially the recent past, in terms of their own lived experience. Central to this creation of memory from individual experiences was the formation and workings of the Truth and Reconciliation Commission (TRC). The TRC made possible a public understanding of the past by way of testimonies of individual people who, through their own recalled memory, contributed to " $[\mathrm{t}]$ he production of a shared national history... understood to be an integral part of the new nation-building project”(Posel \& Simpson, 2002: 2). Accompanying this public attention to oral history have been more private explorations of its possibilities by a variety of institutions and individuals, encouraged by new history curricula, the Heritage legislation of 1999, and the Department of Arts and Culture.

A new and growing dimension of oral history in South Africa, that gained momentum with the TRC, is the notion of 'testimony as oral history.' The field of oral history is filled with internal debates; most oral historians, however, would not define testimony 
and oral history as synonymous. They would argue two principal approaches to oral history: first, collecting as many oral testimonies as possible around the same events to look for corroboration (Vansina, 1985; Delius, 1996); or, second, using multiple oral testimonies to illuminate perceptions of the past and meaning-making about the relationship between past and present (Hofmeyr, 1993; Nthunya, 1996).

Despite these methodological safeguards, tendencies to regard memory as 'fact' and/or testimony as ‘truth' have been the subject of recent debate, particularly as history-making has been public and political. The TRC highlighted difficulties of determining 'truth' and representing 'history.' Posel and Simpson describe how TRC hearings were shaped by "powerful epistemological myths about the primacy and authenticity of direct experience-_seeing'—in recounting truth”(2002: 7). A blanket acceptance of this testimony as 'fact' and 'truth', they argue, did (and does) not allow for the interpretive nature of the process of 'remaking history' to be acknowledged and grappled with publicly. As a result, “[t]he ‘truth’ would be told in terms of simple moral binaries of 'victim' and 'perpetrator', associated with unambiguous judgements of right and wrong. There was no place here to explore moral ambiguities... nor to explore the complexities of social causation” (Posel \& Simpson, 2002: 10). Public events such as the TRC are, in a Foucaultian sense, pedagogical. They are sites of the construction of reality in which viewing-subjects, as learners, engage with the facts that are placed before them through testimony and make judgments (Soudien, 2002). Yet without the space for critical questioning, interpretive dialogue, and dissent, the pedagogic role of the TRC was truncated. 
Classrooms, however, do provide space for complexity and ambiguity. They provide space to address what Giroux describes as the tension between "the modernist emphasis on the capacity of individuals to use critical reason to address the issue of public life [with] a postmodernist concern for how we might experience agency in a world constituted in differences unsupported by transcendent phenomena or metaphysical guarantees”(1991: 52). They provide space to mediate being “trapped between fundamentalists who believe they have found truth, and relativists who refuse to pin it down”(Fernandez-Armesto, 1998: 3). It is toward the creation of just such spaces that history teachers engage in telling their own stories in the classroom. Through testimony, teachers are creating space for dialogical memory making in the new South Africa.

\section{Education Reform in South Africa: Changing Ideology of History Teaching}

The National Party government of 1948 to 1994 engineered a segregated and unequal education system. It was designed to serve the apartheid state ideologically and economically (Kallaway, 1984, 2002; Hyslop, 1999). 'Separate development' was manifest in different Departments of Education; students could only attend schools that accorded with their population groups, and funding between the Departments was widely divergent; in 1969-70 for every one rand spent on an African child, R4,29 was spent on a so-called colored child, R4,76 on an Indian child, and R16,59 on a white child (Christie, 1985; SAIRR, 1994: 690). ${ }^{\mathrm{ii}}$

History teaching was critical to the government's strategies for apartheid education. The history taught in schools was ideologically and politically linked to the regime, serving to explain and legitimise the racial hierarchy of South African society and to 
teach students about their place in that hierarchy. Contrary to the dictates of separate development, there was little difference in the formal school history curriculum between Departments (Siebörger, 2005). In all schools, the taught history created a vision of legitimate domination by a white minority (Bam \& Visser, 1997; Chisholm, 1981; Du Preez, 1983; Lamont and Lobban, 1985).

The need to replace the apartheid school history syllabi quickly prompted the Minister of Education, in 1994, to initiate a review of the existing 1985 curriculum. The subcommittee for history conducted an "evaluation of the existing core syllabus with regard to inaccuracies resulting, inter alia, from the new constitutional dispensation, as well as outdated and contentious content” (Lowry, 1995). In January 1995, all of the provinces implemented the resulting interim syllabus for history. This new syllabus listed a choice of topics for each grade and left it to individual teachers to choose between the topics and to devise the specific content and methodologies. It was no less specific than the previous syllabus, but the relationship between departments of education and teachers now allowed—and encouraged—a flexible interpretation, especially since the government did not provide new textbooks to replace old ones (Siebörger, 2000: 41).

The interim syllabus presented a rationale for the study of history to guide teachers' implementation of this curriculum.

History is a systematic study of the past. It is a study based on evidence: a selection of facts and events that are arranged, interpreted and explained. Thus History, in addition to its content, is also a mode of enquiry, a way of investigating the past which requires the acquisition and use of skills..... [A] study of recent History is essential for an understanding of the present, just as an understanding of the present is necessary to understand the past (WCED, 1995). 
The philosophy of history teaching was clear and ambitious in the interim syllabus. Yet it also allowed space for individual teachers to bring their own ideas into the classroom and to respond to the demands of particular school situations. It was flexibility that characterised the interim syllabus; it was intended as "guidelines only, [and] lets the teacher do the rest” (Weldon, interview). ${ }^{\mathrm{iii}}$

Into this curricular flexibility entered the testimonies of teachers in history class. Teachers had space to shape their own curriculum and no longer faced the threat of government Inspectors telling them what they could and could not do. With this freedom, and uncertainty, some teachers felt the need to stick to the familiar syllabus, or—with lack of access to resources—-were bound to outdated textbooks that reinforced the ideas of the old syllabus. Nevertheless, every teacher had become free to speak his or her mind in the classroom. And the exercise of this freedom became widespread. Often, sharing one’s own experience became a substitute for the printed history resources that were lacking in schools.

\section{Study Design}

How do teachers perceive and understand their teaching of history in a new South Africa? Research on this central question, conducted in Cape Town high schools in 1998 and in 2001, sheds light on the use of teacher testimony in schools. During 1998, Sarah Dryden-Peterson conducted ethnographic research in sixteen high schools, collecting data in four ways: participant-observation of 198 Grade 8 and 9 history classes, semi-structured interviews with 52 history teachers, 32 focus groups with Grade 8 and 9 history students, and extended observations and conversations in 
each school setting. She returned to each school in 2001 to conduct a follow-up study, interviewing the same teachers and students and observing current Grade 8 and 9 history classes.

Four schools, representative of common types of schools in contemporary South Africa, formed the central case studies of this research (see Figure 1 for details). Peninsula High, Transkei High, Plain High, and Central High provided rich data about the experiences of teachers and students in the history classrooms and schools of the Cape Town area. However, these four schools alone could not account for the wide spectrum of teachers and students, schools and education that existed in Cape Town. A desire to inform the central case studies with a broader scope of how teachers and students experienced and shaped their history teaching in a time of transition prompted the expansion of the study to include three 'breadth' schools for each of the central case studies, making a total sample size of sixteen schools.

[Figure 1 about here]

The sources of data for this study were as follows: documents; transcripts of interviews; transcripts of focus groups; and fieldnotes. All interviews and focus groups were transcribed verbatim and coded using etic codes that emerged deductively from the literature on oral history and testimony and emic codes that emerged inductively from the research participants. Analytic memos were created, using these etic and emic codes as organising principles. The memos were further informed by fieldnotes and served as a basis for cross-case analysis. This 
combination of methods was used with the aim of providing insight at the level of the school and teacher and of explaining the larger phenomena of teacher testimony.

\section{History Education in the New South Africa: Teachers as Memory Makers}

The teachers described approaching their teaching of history with two common concerns. First, within the flexibility of the syllabus, they asked themselves what content knowledge they should teach their students. In so doing, they were conscious of the students they taught—-their neighbourhoods, their experiences, and their ideas about the future. Second, they brought to their classrooms perceptions of what South Africa was like in 1998 and in 2001 and what it would be like in the future; they saw the history classroom as a place to teach their students both the content and the skills that would help them to live in their country. These similar concerns emerged from a shared context: the flexibility of a new history syllabus and the changed political dispensation.

However, teachers actualized their pedagogical concerns in different ways, particularly through the use of testimony. Four factors emerged as critical influences on teachers' use of testimony in history classrooms. First, we probe access to resources as a motivation to use testimony. Second, we examine testimony as a substitute for printed materials. Third, we explore the confidence of teachers as enabler or deterrent in bringing testimony to their teaching. Finally, we analyse teachers' perceptions of what is relevant and necessary historical understanding for their students. Divergent social, economic, and demographic contexts of schooling 
emerge as unifying features of these factors and as central influences on teacher testimony.

A critical factor shaping teachers' use of testimony was access to resources. At Central High, teachers had newly-published books, videos, photocopiers, and professional development. Here, teachers did not have to use out-dated textbooks and could be creative, said Mr. Brown, Head of History. "When we sat down to decide on the [Grade 9] course last year,” he explained, “we decided to try and bring the history closer to [the students'] time period. History is often distant. The First World War and the Second World War, they can be interesting. But now we're dealing with people that they know: JFK, Marilyn Monroe, Martin Luther King, Cassisus Clay. We are looking at where these people that they've heard about fit into history” (interview). The teachers at Central High produced course notes on the 1960s-their period of focus—-from resources gathered from personal collections and libraries. They showed students videos about the space race and had them listen to changing technology in music recordings. Working together, the teachers at Central High produced a curriculum that engaged their students and responded to a particular understanding that they felt necessary for these students: how political change can impact society (Brown, interview).

The ability to draw on these resources was a luxury not all schools had, the teachers at Central High recognised. Ms. Higgins, Head of History at a similarly well-financed former House of Assembly school, described how changes in history in South Africa were taking place on an unlevel playing field. "Many of the schools from the same kind of educational background as ours do [use these different approaches]. I think 
the problem in the under-resourced former-DET [African] schools, I don't think that's being done. And understandably. To do that kind of stuff, you need to have access to photocopiers and sources and libraries and that has been a problem. It still is a problem” (interview).

Mrs. Ndima at Masakhane High, a former-DET school, echoed these concerns. "Many of the people in a situation like this school say it is impossible to make education good,” she said. “At many schools, teachers have lost their hope. They believe our children will fail....[W]e don't have all the equipment and we don't have the funds because of the area” (interview). But Mrs. Ndima actively sought out resources she could use in class to make history relevant, interesting, and part of a broad project of education reform in the new South Africa.

In many under-resourced schools, like Mrs. Ndima’s, what teachers had was their own stories. "Now we have freedom and we can do whatever we want," said Ms. Septoe at Plain High, echoing the excitement of many other teachers about the possibilities for history teaching under the interim syllabus (interview). Despite the will to innovate, Ms. Septoe encountered numerous challenges in making her history classroom a place of “new ideas” of democracy, non-racialism, and tolerance, reflecting both the backgrounds of her students and the new dispensation in South Africa (interview).

In her own search for resources, Mrs. Ndima described a similar struggle: “These people are so disadvantaged. The only thing is to make [the students] respond to whatever you're telling them...it's just to talk to them. I don't have the other ways” 
(interview). In 'just talking' to their students in history class, teachers in South Africa had begun to tell their own stories of life under apartheid. They were using testimony as a pedagogical tool.

Ms. Septoe explained how the necessity of and belief in testimony was transformed into classroom practice. She said, “I told them especially about Plain High’s past in the apartheid struggle and they were enjoying it.... Every day when they came, they wanted me to tell them about the history of Plain High in the apartheid struggle. Because they didn’t experience that. They want to hear about it” (interview). In a conversation in the staff room, she explained to me what she explained to her students in a previous class. Plain High opened in 1983, a time when the apartheid government was forcibly removing so-called coloureds from their homes in Cape Town. Those areas, she said, had been declared 'whites-only.' People were moved predominantly to Mitchells Plain, a vast expanse of sandy land outside Cape Town. "That was my experience, as well, and I tell my class that.... They need to know" (personal communication).

“I was not a teacher at this school in those days,” Ms. Septoe said. As a result, Ms. Septoe could not use her own experience to testify to this history; however, she found resources in other teachers. She said, "But Mr. September [another teacher at the school] has told me about [this period in the school's history].... I use his stories in my classes” (personal communication). “[T]his school played a major part in the liberation struggle of South Africa,” Mr. September testified to his colleagues and to his students. "We were one of the few schools that was in protest with the Government since 1983 up until 1990. There were times in our history when the 
Department tried to close down this school because of our political activity. The first Principal, he lost his job because he gave a commitment to fight apartheid. ... [A]nd a few of our teachers were locked up during the apartheid struggle” (interview \& classroom observation).

The history of Plain High in the apartheid struggle was not only one of protest against apartheid policies but one of defiant action. In class one day, Ms. Septoe overheard one of her students commenting, in a complaining tone, on the late arrival of African students at school, despite knowledge of transportation interruptions in the far-away townships from which they traveled to school. "Did you know" she asked them, "that Plain High was one of the first schools to accept African students? Even back in 1986.... The motto of this school is 'Educate to Liberate.' Do you know what that means? We must make that so today" (classroom observation). "I must talk to them,” Ms. Septoe said. "History is important.... They must know about their past.... Now they understand why it is like this [in South Africa today]. They were so small when we were in the struggle. And they're asking a lot of questions: 'Miss, why was it like that? Why did we have apartheid?' You have to explain” (interview).

In general, as in this example, it was the history of apartheid that teachers taught through testimony. Like Ms. Septoe, they created space through their testimonies for students to ask questions and, with this interactive learning, to come to their own understandings of history. In addition to school history, teachers tesified to their own experiences. To teach a lesson on the Group Areas Act, for example, Mr. September told his story. "I was walking on the beach with my wife one evening," he said. "We were just enjoying the sunset and the fresh air. A policeman appeared, almost out of 
the bushes, and he put handcuffs on us. He took us away, he threw us into his car.... He didn’t ask us any questions. But we did know what we had done. We stepped onto the beach reserved for the Whites, 'Slegs Blankes'.... We spent that night in jail” (interview). Students said that hearing Mr. September's story about the past allowed them a greater understanding of their own history, especially incidents from their childhoods that they did not make sense of at the time (Grade 8 and 9 students, interviews). Teacher testimony had, in this way, become an important pedagogic tool in linking the past to the present.

Teaching by testifying was not only taking place in under-resourced schools. Its second, and perphaps more critical, role was in creating dialogue around the making of a new history for South Africa. In that role, it was important in schools both with resources and without. At Hoërskool Noord, an Afrikaans-medium and former House of Assembly school, Mr. de Groot explained that his students were resistant to South African history. They did not want to learn about South Africa's past because they already felt that they were being made to live in the past, to take the blame for what their white ancestors did (interview). Despite the inclinations of his students, Mr. de Groot veered away from history of the World Wars on which he did have resources to focus on history he felt was applicable to the futures of his students. This history, he felt, was recent South African history. Mr. de Groot was unwavering in his commitment to help his students lose their cynicism about the new South Africa. "To me,” he said, “... [history’s] about giving them hope despite what they may see as a hopeless situation. To give them hope and to make them dream and to let them plan to accomplish those dreams” (interview). 
Mr. de Groot exposed his vision of what history can do in the new South Africa to his students through testimony. "I remember seeing coloured people holding hands a few year ago," he told his students, "and realising for the first time that those people could love like I do” (personal communication). Mr. de Groot’s testimony in class focused on his struggle to rid himself of the blinders with which he grew up. He testified from his own learning experience: “[W]e all were products of an education system that they called...Christian National, so everyone was like the same. You thought the same, they thought the same, the way they taught was the same....But I want to make the pupils see that it's so normal to talk to each other,... just to play sport together, you know, just to sit in class together; it's so normal to go to one's houses together, to have maybe just a party together... [O]ur previous system made it abnormal to do it. For instance ... I never see a coloured man or a black man in my folks’ house, other than they came to work there or they came to beg, nothing else. And these people, they see the same. So ... say if I invite somebody over to my house and it's a coloured man or a black man, it’s abnormal in a way, you know. So I want to change that to being normal” (interview). In this way, teacher testimony was a tool not only in opening possibilities for alternatives to the once 'official' history in South Africa but in helping students to imagine a new future.

As at Plain High and Hoërskool Noord, the teachers at Transkei High were outspoken on the need to focus on recent history to engage with students around what they needed to know to live in South Africa, in the present and future. "Children must know what’s happening today! They want to know!” Mrs. Fanaphi exclaimed. Mrs. Mahashe, her colleague, looked at "those old books" on her desk and dismissed them. "You can create a lesson without even going to the textbook," she asserted 
(interview). Yet despite these possibilities for history teaching, students at Transkei High learned very little in history classes. While the students waited in their classrooms for history classes to happen, their teachers sat in the staffroom, convinced that not enough students would show up to make class worthwhile. The teachers never checked, though (personal observation). When history classes did happen, once in three weeks for each class, Mrs. Mahashe did not say anything but simply wrote notes on the board for her students to copy. The topic was the Renaissance. It was the first topic in the syllabus, the first topic in the textbook, the first topic they had covered all year. And it was July, the beginning of the third term (personal observation). Despite the fact that the old syllabus was teaching, as students described it, “a wrong subject” (Grade 8 student, interview), Mrs. Mahashe and Mrs. Fanaphi did not feel confident testifying to a different history. Without this confidence to testify and without a concrete replacement for the old and 'wrong' syllabus, teachers at this former-DET (African) school as well as at former-DET breadth schools decided that the best option for history was simply not to teach it.

At a similarly homogeneous, but white, school, teachers did not use testimony about the recent South African past because they did not believe it relevant to their students. Mrs. Fieldings explained that European and American history was appropriate to the community Peninsula High served; students at this school related closely to overseas history because it resonated with their life experiences (Fieldings, interview). The teachers at Ocean High agreed with this philosophy. Mr. Will, Head of History, explained why they taught European history. "It tends to be Eurocentric because [the students] have a strong resistance to doing South African history. They have a much 
closer connection to things like World Wars than the little battles here in South Africa” (interview).

Teachers' perceptions of what was relevant and necessary historical understanding for their students emerged as a critical factor shaping the use of testimony in history classrooms. Teachers at schools that had become integrated in the decade since the fall of apartheid argued that it was not the 'appropriateness' of certain kinds of history or a lack of confidence that prevented teachers from testifying; on the other hand, testifying had developed among an increasing number of teachers out of necessity.

Ms. Hofmeyr, at Mountain High, said "cultural difference is actually forcing us to do the job [of history teaching] better than we did before” (interview). Agreeing, Ms. Matthews of Central High explained that cultural difference, and the accompanying multitude of perspectives, was what made testimony possible for her. "I think it must be terribly difficult for teachers at schools that are still so racially divided to teach about diversity and about the new South Africa. Empathy only goes so far,” she sighed. “The new South Africa hasn’t reached those areas yet” (interview). Central High was different than Transkei High and Peninsula High: “Our kids are having the chance to experience the diversity of South Africa,” explained history teacher Ms. Roberts. "But we must help them. History can help them to have the discussions they need to have, to understand each other. They must learn to live in the kind of South Africa that is made up of diverse people, who are equal. That's hard for some of them. But as history teachers, we're trying” (interview). Testimony was a way for these teachers to bring dialogue and dissent to their pedagogy. 
The use of testimony was experimental and informal for some teachers; for others, at schools locked in apartheid-era segregation, testimony was simply not happening. However, in several settings, testimony had become an organising principle around which teachers built almost every history lesson. While no one factor emerged as determinant in influencing this testimony, access to resources, a predeliction to create space for discussion of a new history for South Africa, teacher confidence, and a perceived relevance and necessity for testimony combined to play critical roles in multiple school settings. Central to the impact of these factors were social, economic, and demographic contexts of schooling: traditions of testimony stemming from the apartheid struggle combined with a lack of resources, such as at Plain High; a perceived necessity to employ testimony as a way to integrate thinking at racially homogenous schools, such as Hoërskool Noord; and increasingly diverse student populations in recently integrated schools, such as Central High. Ten years after apartheid, these are common situations: many schools continue to be under-resourced, many school are becoming increasingly diverse, and many schools remain racially isolated. In all three of these situations, testimony emerged as an important pedagogic tool for history and as a potentially critical means to developing a vision of South Africa based on democracy and non-racialism among the next generation.

\section{Teacher Testimony in Classrooms: New Possibilities for School History}

The pedagogical nature of testimony in the new South Africa provides an indispensable teaching tool. In recognising the value of the stories of teachers who fought apartheid or who have made a transformation in its aftermath, one constructs the possibility for using testimony in the process of public construction (and 
destruction) of memory and of social change in education - the very institutions that we have argued are central to new visions for South Africa taking hold.

Our aim has been to better understand the role of history teachers as mediators of memory making in South African schools and, in so doing, to explore teacher testimony as a pedagogic tool and to open the door for scholarly attention to this topic. While there has recently been a push to use oral history in under-resourced schools globally_-including in South Africa—-the focus has been on students as oral historians (Bam \& Visser, 1997; Bickford-Smith et al, 2001). The oral testimonies of teachers have rarely been examined and the use of this testimony in classrooms as a pedagogical and transformative tool has not been the subject of previous inquiry. This sample of sixteen Cape Town schools, however, suggests that teacher testimony is happening, daily, in many South African schools. The implications of teachers as memory makers thus need to be examined.

Personal narrative_-in the form of biography, autobiography, oral history, and testimony-has particular power in reaching an audience on a human level, a characteristic often absent in other forms of historical work or teaching. In this way, teacher testimonies are an effective pedagogic tool: they are engaging stories that reach students on a personal level while at the same time shedding light on a wider context of historical time. The power of testimony is not only in the details of an individual experience; it is in the way that stories allow for understanding the context of South Africa at the time in which individuals lived and worked.

This account of Cape Town schools suggests that the use of teacher testimonies in 
classrooms, while a new development and not universal, holds potential to enrich the experiences of history students - the citizens of the future-in South African schools. In addition to the pedagogic qualities outlined above, testimony plays a particularly important role in under-resourced schools, which are the majority in South Africa today. As teachers have commented, there are few resources available for history instruction and yet personal testimony is readily accessible in every school. Teachers at Plain High and Masakhane High explained that their own testimonies took the place of teaching from apartheid-era textbooks. Further, at under-resourced and wellresourced schools alike, teachers felt that they were able to teach values of nonracialism, tolerance, and respect through their testimonies. Teachers in fact felt this method of teaching history was successful for the same reason that human stories have the power to educate: the voices that teachers brought to their own classrooms portrayed the atrocities of apartheid and developed in students convictions of 'never again' while at the same time celebrating the triumph of the human spirit and the collective value of democracy in South Africa. In exposing these tensions, teacher testimony promotes space for deliberation among students, skills that will be critical to their participation in the ongoing practice of democracy.

While teacher testimony can be effective in these ways, advocating its use in classrooms comes with a warning, for South Africa and for other countries in which democratic transition means a rethinking of history. If presented uncritically as 'fact' or 'truth', just as 'official' history once was, it could promote hatred and provocation rather than creating space for deliberation of democracy and non-racialism. For this reason, few parents, teachers, or historians would disagree that students need to be exposed to multiple sources and to participate in dialogue and dissent in order to 
achieve a nuanced and rich understanding of history. The past of South Africa certainly is instructive on the danger of placing history in the hands of few.

Yet, there may also be danger in placing history in the hands of many. Indeed, a public construction of memory such as the TRC or more broadly-based teacher testimony in schools may be as much a process of collective forgetting as it is of remembering. As Eric Foner writes, “[t]he dilemma of South African popular history today is that historians may not produce the history the 'people' are looking for” (Foner, 2002: 102-3). At any time, in any place where a certain history is soughtand the 'people' are called on publicly to create it - there is a danger of selective forgetting.

The construction of memory in South Africa was, in the past, under the control of a white minority. The history taught in school was a result of this construction and was ideologically and politically linked to the apartheid regime. The question of who creates history and how it becomes legitimate is thus of particular concern in postapartheid South Africa. The Truth and Reconciliation Commission represented a collective attempt to place the construction of memory in the new South Africa in the public sphere. Yet, the process of the TRC is over. However, the need and desire for public deliberation of the past, in a way that can be contributed to and accessed democratically, is not (Jeppe 2004: 32-35). Teacher testimony is an important continued source of public memory-making in a South Africa ten years into democratic change. History classrooms, in particular, are critical spaces for dialogic and inclusive memory-making. The experience of those teachers and students making 
history in this context indeed may help to continue the work of the TRC, striving to meet goals of national reconciliation and unity. 


\section{References}

Bam, J. and P. Visser. (1997) A New History for a New South Africa. Kagiso Publishers. Cape Town.

Bickford-Smith, Vivian et al. (2001) In Search of History: Secondary Book 1. Oxford University Press. Cape Town.

Bozzoli, Belinda \& Peter Delius. (1990) Radical History and South African Society. Radical History Review 46:7, 13-45.

Chisholm, Linda. (1981) Ideology, Legitimation of the Status Quo and History Textbooks in South Africa. Perspectives in Education 5:3.

Christie, P. (1985) The Right to Learn: The Struggle for Education in South Africa. Ravan. Johannesburg.

Cohen, David William et al. (2001) Introduction: Voices, Words, and African History. In African Words, African Voices: Critical Practices in Oral History, eds. Luise White et al. Indiana University Press. Bloomington.

Delius, Peter. (1996) A Lion Amongst the Cattle: Reconstruction and Resistance in the Northern Transvaal. Ravan. Johannesburg.

Du Preez, J.M. (1983) Africana Afrikaner: Master Symbols in South African School textbooks. Librarius. Alberton

Fernandez-Armesto, F. (1998) Truth: A History and a Guide for the Perplexed. Black Swan. London.

Foner, Eric. (2002) Who Owns History? Rethinking the Past in a Changing World. Hill and Wang. New York.

Giroux, Henry A. (1991) Border Pedagogy and the Politics of Postmodernism. Social Text 28, 51-67.

Hofmeyr, Isabel. (1993) 'We Spend Our Years as a Tale that is Told': Oral Historical Narrative in a South African Chiefdom. Witwatersrand University Press. Johannesburg.

Hyslop, Jonathan. (1999) The Classroom Struggle: Policy and Resistance in South Africa, 1940-1990. University of Natal Press. Pietermaritzburg.

Jeppe, S. (2004) Africa: Whose history? Whose memory? In Toward New Histories for South Africa, ed. S. Jeppe. Juta. Cape Town.

Kallaway, Peter (Ed). (1984) Apartheid and education: the education of Black South Africans. Ravan Press. Johannesburg.

Kallaway, Peter (Ed). (2002) The History of Education Under Apartheid, 19481994: 'The Doors of Learning and Culture Shall Be Opened.' Maskew Miller Longman. Cape Town.

Lamont, R. and S. Lobban. (1985) A Study of bias in Bantu Education Department school history textbooks. Faculty of Education, University of the Witwatersrand.

Lowry, Stephen (1995) A review of the history curriculum process. In Proceedings of the Workshop on School History Textbook Writing: From principles...to Practice, eds. J. Reid \& R. Siebörger. Project for the Study of Alternative Education in South Africa. Rondebosch.

Minkley, Gary \& Ciraj Rassool. (1998) Orality, memory, and social history in South Africa. In Negotiating the past: The making of memory in South Africa, eds. Sarah Nuttall \& Carli Coetzee. Oxford University Press. Cape Town.

Molteno, Frank. (1987) Students Struggle for Their Schools. Centre for African Studies, University of Cape Town. Cape Town.

Nthunya, Mpho 'M’atsepho. (1996) Singing Away the Hunger: The Autobiography of an African Woman. Indiana University Press. Bloomington. 
Posel, Deborah and Graeme Simpson. (2002) The Power of Truth: South Africa's Truth and Reconciliation Commission in Context. In Commissioning the Past: Understanding South Africa's Truth and Reconciliation Commission, eds. Posel \& Simpson. Witwatersrand University Press. Johannesburg.

Reeves, Cheryl. (1994) The Struggle to Teach. Maskew Miller Longman and Sached Books. Johannesburg.

SAIRR (1994) Race Relations Survey 1993/94. South African Institute for Race Relations. Johannesburg.

Siebörger, Rob. (2000) History and the emerging nation: the South African experience. International Journal of Historical Learning, Teaching and Research $1: 1,39-48$.

Siebörger, Rob. (2005, forthcoming) The Dynamics of History Textbook Production During South Africa's Educational Transformation. In 'What Shall we Tell the Children?' International Perspectives on School History Textbooks, eds. Keith Crawford \& Stuart Foster. Information Age Publishing. Greenwich CT.

Soudien, C. (2002) Memory Work and the Remaking of the Future: A Critical Look at the Pedagogical Value of the Truth and Reconciliation Commission for Peace. In Peace Education: The Concept, Principles, and Practices Around the World, Gavriel Salomon \& Baruch Nevo. University of Haifa Press. Haifa.

Vansina, Jan. (1985) Oral Tradition as History. University of Wisconsin Press. Madison.

WCED. (January 1995) Interim Syllabus for History Ordinary Grade, Standards 5, 6, and 7. Department of Education, Western Cape.

Wieder, Alan. (2003) Voices from Cape Town Classrooms: Oral Histories of Teachers Who Fought Apartheid. Peter Lang. New York. 
Figure 1. Explication of Cases

\begin{tabular}{|c|c|c|c|}
\hline $\begin{array}{l}\text { Central Case } \\
\text { Studies }\end{array}$ & Breadth Schools & Characteristics & $\begin{array}{l}\text { Average } \\
\text { School Fees } \\
\text { (1998) }\end{array}$ \\
\hline Peninsula High & $\begin{array}{l}\text { Ocean High } \\
\text { Hoërskool Noord } \\
\text { River High }\end{array}$ & $\begin{array}{ll}\text { - } & \text { former House of Assembly schools } \\
\text { - } & \text { students and teachers predominantly } \\
\text { white }\end{array}$ & R3266 \\
\hline Transkei High & $\begin{array}{l}\text { Longevity High } \\
\text { Khayelitsha High } \\
\text { Masakhane High }\end{array}$ & $\begin{array}{ll}\text { - } & \text { former Department of Education and } \\
& \text { Training (DET) schools } \\
\text { - } & \text { students exclusively African } \\
\text { - } & \text { teachers predominantly African } \\
\end{array}$ & $\mathrm{R} 50$ \\
\hline Plain High & $\begin{array}{l}\text { Flats High } \\
\text { Freeway High } \\
\text { District High }\end{array}$ & 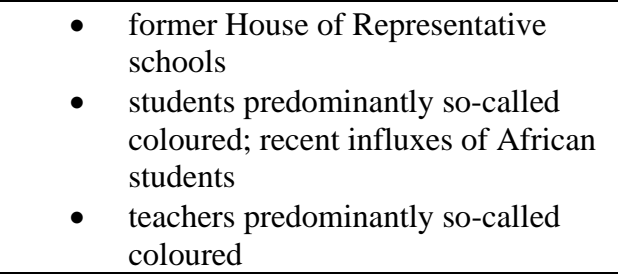 & R205 \\
\hline Central High & $\begin{array}{l}\text { Suburb High } \\
\text { Community High } \\
\text { Mountain High }\end{array}$ & 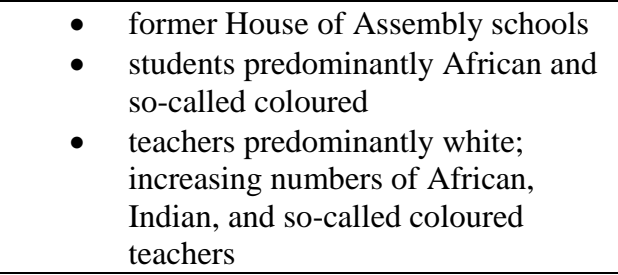 & R2612 \\
\hline
\end{tabular}




\section{Notes}

${ }^{\mathrm{i}}$ The Rotary Foundation supported this research. We would like to thank Suzanne Grant Lewis, Mark Warren, and the students in the Communities and Schools Pro-seminar at the Harvard Graduate School of Education, especially Allistair Witten and Soo Hong, for insightful comments on this article. We also acknowledge the helpful comments of two anonymous reviewers.

ii In the past, racial terminology was used to ascribe worth or non-worth to individuals and to groups in South Africa. Despite the fact that this terminology has been rejected on a large-scale, it still has currency to convey the history of inequalities or for purposes of equity. We have used the racial descriptors that teachers and students in Cape Town schools used most often to describe themselves, hence, so-called coloured, African, Indian, and white.

iii Gail Weldon, Western Cape Education Department, 30 June 1998. Flexibility has remained a key aspect of curriculum design post 1995. 'Curriculum 2005', first introduced in 1998 (and into Grade 8 in 2001) was a completely reconceptualised curriculum, which did not mention history, but included historical topics within 'Human and Social Sciences'. Following the report of a review committee in 2000, this curriculum was substantially altered in 2002, and re-introduced as the Revised National Curriculum Statement. History was brought back and its content knowledge specified by grade, though there is still flexibility. The curriculum encourages the study of local history, oral sources, indigenous knowledge, human rights and democracy. (It will be introduced in Grade 8 in 2006.) 